Misr J. Ag. Eng., 26(2): 1021- 1035

BIOLOGICAL ENGINEERING

\title{
PERFORMANCE EVALUATION AND MODIFICATION OF THE JAPANESE COMBINE CHOPPING UNIT
}

\author{
El-Hanfy, E. H.* and S. A. Shalby**
}

$\underline{\text { ABSTRACT }}$

The main objective of this research is to maximize utilization of Japanese combine by improving chopping unit to chop rice straw during harvesting process. The performance of the chopping unit was evaluated under four forward speed $(0.35,0.55,0.75$ and $1 \mathrm{~m} / \mathrm{s})$, three cutting speed (450, 550, $650 \mathrm{rpm})$ and three distance overlapping between fixed and rotary knives $(6.0,8.0,10.0 \mathrm{~cm})$.

The main results can be summarized as follows:

1- The average of cutting length decreased and the distribution percentage of short pieces increased by increasing each of forward and cutting speeds and overlapping between fixed and rotary knives.

2- The highest percentage value (83\%) of short pieces $(<6 \mathrm{~cm})$ were obtained at "0.75m/s, 550rpm, 10cm" forward and cutting speeds at overlapping between knives respectively.

3- The highest field capacity $(0.68 \mathrm{fed} / \mathrm{h})$ and productivity $(2040 \mathrm{~kg} / \mathrm{h})$ were obtained at "0.75m/s and 550rpm" forward and cutting speeds.

4- The power consummation was increased with increasing forward and cutting speeds, while the energy requirement ( $k W . h / t o n)$ increased with decreasing forward speed and increasing cutting speed.

\section{INTRODUCTION}

Crop residues are one of the most critical problems, which face the Egyptian farmer specially after harvesting different field's crops. It is well known that rice is considered as one of the most widely cultivated cereal crops in Egypt. Rice harvesting by combine without chopping is a serious problem facing Egyptian farmer. To clear the fields from the rice straw, the Egyptian farmer exert effortless to burn straw. Yearly, the Egyptian

\footnotetext{
* Inst. For Efficient Productivity, Zagazig Univ. Egypt.

** Agric. Eng. Res. Inst., (AERI) Egypt.
} 
farmers burn about 2.5 million ton of rice straw (El-Berry et al., 2001) for disposing it and gave the chance to prepare the soil for next crop. This way of burn the rice residues in the farms cause of serious phenomenon of ground and air pollution. On the other side, the quantity of crop residues in Egypt reached about 18.75 million ton per year and the national income might be increased with 1.6 billion LE / year if we try to recycle it (ELBerry et al., 2001and Awady et. al. 2001).

Thus, there are great efforts towards recycling rice straw in a useful ways will help keeping friendly environment and lead to increase the national income. Therefore straws' chopping is necessary as a pretreatment to incorporation into the soil or to reuse it in other different uses. The chopping process can be done by using variable type of chopping machines, but the capacity of these choppers is still little, not covering the farmer's needs and the high cost of chopping process (Arif, 1999). On the other side, some researchers reviewed chopping agricultural residues and the engineering factors affecting on the chopping process such as:-

Kanafojrki, et al. (1976) mentioned that during the cutting processes of agricultural plant a cutting knife penetrates into the material, overcoming its strength and separating it. Throughout this process, various deformations occur in the material, depending on the form of the cutting edge and the kinematics of the cutting process.

EL-Eraqi et al. (2003); Imbabi (2003) and Kamel et al. (2003) indicated that, the cutting length of crop residues is decreased by increasing feeding rate, cutter head drum speed, cutting knives number and decreasing the clearance between fixed and rotary knives.

Kepner et al. (1993) mentioned that dull knives and excessive clearance lead to increase cutting energy this due to the crop tern rather than sheared and also accelerates wear due to wedging between the knives and shear bar. Abdel Maksoud et al. (1998) manufactured locally a straw chopper and mounted it on a John Deer combine; they studied the influence of some factors effects on the process of chopping straw, their results indicated that the specific energy decreased with increasing row spacing, clearance between free and fixed knives, decreased forward speed and moisture 
content. Khadr (1997) studied the interaction effect between different speeds of cutter head and number of knives for cutting some field crop residues. He found that the cutting length decreased by increasing knives number and cutter head drum speed and also added that increasing cutter head knives decreased the horsepower consumed, meanwhile increasing cutter head drum speed causes an increase in the horsepower consumed.

Yumnam, and Partep (1991) and Habib et al. (2002) reported that the cutting energy requirement of forage crop is mainly affected by tow factors namely physical and mechanical properties of plant stem and the cutter head parameters, whereas, for the machine working performance, the main parameter is the cutting rotational speed. Srivastava et al. (1995) divided the power use in cut and blow forage chopper as follows: $20 \%$ to gathering and feeding, $40 \%$ to the cutter head, and $40 \%$ for plowing. They added that power for chopping influenced by feeding rate, cutting length, sharpness and clearance knives. Ismail (1999) indicated that, field capacity and efficiency of the combine in harvesting rice ranged from 0.44 to $1.5 \mathrm{fed} / \mathrm{h}$ and field efficiency ranged from (59.2 to $70.2 \%)$ respectively. Nasr (2000), reported that the productivity of the chopper is proportional with drum speed, moisture content and feeding speed. Also, Luis et al. (1993) found that rice straw cut to appropriately length, which can be used in composting as the particular cutting size as the residues should be within the range of about $1.27-7.62 \mathrm{~cm}$.

In recent year, many kinds of chopping machines have been manufactured in Egypt to deal with crop residues. This lead to waste time, power and increase a production cost. From this view, it's important that to development of the combine performance by modifying its chopping system to increase the combine efficiency in chopping straw during harvesting crop.

The main objectives of this study are:

1- Modify and test a combine chopping system to suit for chopping straw during harvesting process with suitable particle size.

2- To study the effect of some parameters on chopping performance.

3- To select the best condition to give the desired cutting length.

4- Avoid the clogging problem in chopping system. 


\section{MATERIAL AND METHODES}

Combine machine used in the present study is small size $(140 \mathrm{~cm}$ cutting width). The combine was providing by diesel engine at rated power of $43 \mathrm{HP}$ with air calling system. After the threshing process the straw are delivered via two feeding chain to the rear of combine, then to the chopping chamber. The common problem in chopping system of combine rice machine is the stems accumulate in the chopping chamber specially when increasing forward speed. This is may be due to the straw deliver in axial flow to cutter drums. Then, long rice straw tied on the rotating shaft of cutter drums and this almost accompanied by deformation in bending and tension, which increases the amount force required for the cutting operation. There fore the chopping system failed to cut the rice straws. This problem causes wasting time, less productivity and increase cost. It's necessary to modify feeding and chopping system. Feeding mechanism was modified by change the angle between two parts of feeding chain into straight angle to be sure that the straw is deliver and positively metered in parallel direction on the cutter drum excess to avoid the previous problem.

The modified chopping mechanism was provided by rotary cutter, fixed knives, and rotary impeller blades as shown in Fig. (1) and in photograph Fig. (2).

Rotary cutter: The modified mechanism was provided by one horizontal hexagonal cutter rotor mounted on two ball bearings (instead two horizontal units on original system). The cutter unit conformed from number of serrated disk knives, which have a diameter of $17 \mathrm{~cm}$ and thickness of $2 \mathrm{~mm}$ with interval space of $3.5 \mathrm{~cm}$. The interval spaces were kipped stable by using spacer between serrated knives. The motion was transmitted from power source to cutting rotor by three gears with different diameter to obtain different rotational speed (450, 550, and 650rpm).

Fixed knives: The bar was mounted on a common frame attached to variable three mounted paints, contains 25 links. At end of each link have the fixed knives with shape $(U)$ around rotary knife with clearance $2 \mathrm{~mm}$. The rotor knives rotate between the two edges of fixed knives. 


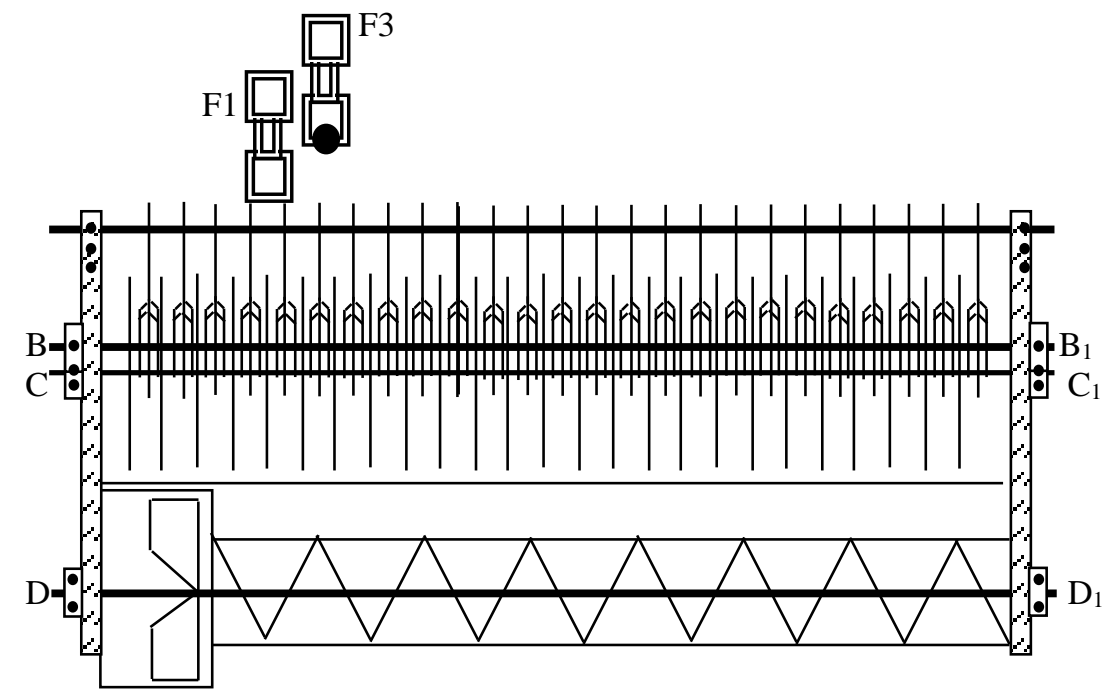

\section{ELEVATION}

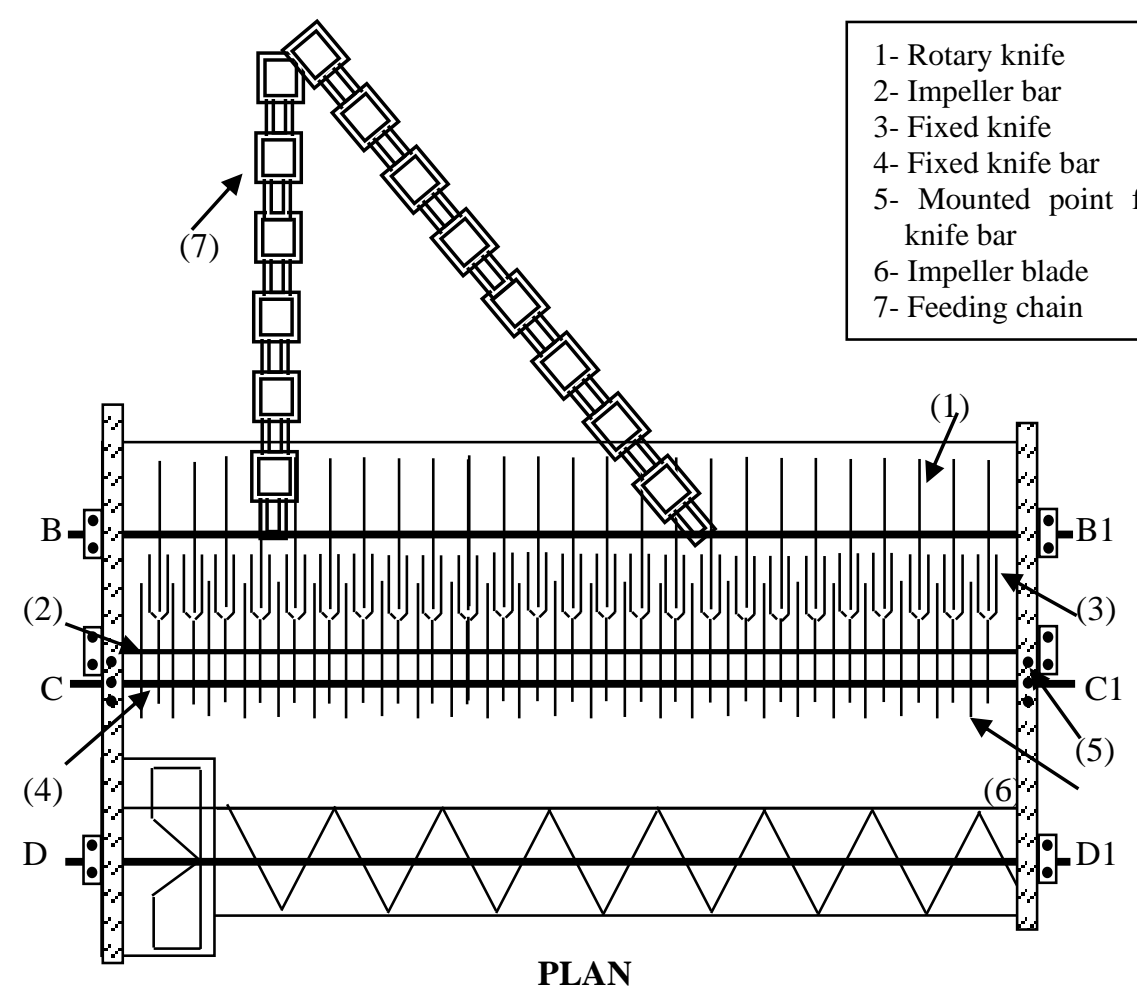

Fig. 1: The layout of shopping unit. 

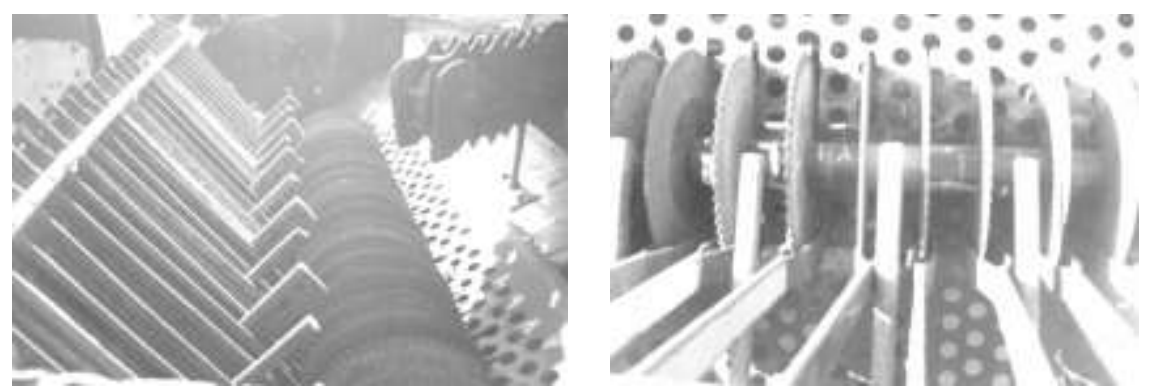

Fig. 2: The chopping unit photograph

It's possible change the overlapping between rotor and fixed knives by changing the position of supported link on the common frame by the variable three mounted points as shown in Fig. (1).

Impeller blades: The chopping mechanism was provided by rotary bar welded on it four rows of impeller blades. Every row has 23 blades $(17 \mathrm{~cm}$ length and $3.7 \mathrm{~cm}$ height with space between blades of $3.5 \mathrm{~cm}$ ). The rotary impeller bar mounted on two ball bearings and connected to the motion of the cutting rotor with constant speed rotation ratio (1: 4.4). Each of impeller blades rotate in between two of fixed knives. These motions lie in vertical plane and parallel with the direction of discharge cutting straw.

The auger with $100 \mathrm{~cm}$ length, $12 \mathrm{~cm}$ outer diameter and $14 \mathrm{~cm}$ pitch was mounted in the rear of combine. At the end of auger has a fan which throws the chopping straw out the combine.

Chopping mechanism operation: In order to perform the cutting operation in this mechanism, moving knives (rotary disk knives) and another resting knives (fixed knives) are participate in the cutting process. The cutting rotor disk knives are responsible for cutting operation and the other fixed knives supports the material during the cutting process to provide the resistance against the cutting force. During the straw cutting process the cutting edge of disk knives penetrates into the stalks of straw, overcoming its strength and thereby cutting it.

The impeller blades rotate in vertical plan and overlapping with fixed knives to facilitate feeding stalks toward cutting system to be sure that the stems is compressed and positively entered into the cutting system. After cutting process is completed and to avoid the accumulation of chopped straw, the impeller blades impel its till do out through auger.

Misr J. Ag. Eng., April 2009 
The experimental work was carried out during rice harvesting season of 2008 (sakha 101 variety) at research farm station of Garbia governorate to evaluate the operating parameters effecting on chopping process. To fulfill the objective of this research work some of the parameters taken into consideration as fallow.

1. Four forward speed (" $F_{1}=0.35 " ; \quad " F_{2}=0.55 " ; \quad " F_{3}=0.75 "$ and "F $\mathrm{F}_{4}=1.0 " \mathrm{~m} / \mathrm{sec}$ )

2. Three cutting rotor speed ("R $=450 " ;$ " $\mathrm{R}_{2}=550 " ;$ " $\mathrm{R}_{3}=650 \mathrm{rpm} "$ )

3. Three overlapping between fixed and rotary knives $\left(" \mathrm{Ov}_{1}=6 "\right.$; $" \mathrm{Ov}_{2}=8 "$ and $\left." \mathrm{Ov}_{3}=10 \mathrm{~cm} "\right)$

\section{Measurements}

Cutting length: After each chopping treatment, random sample $(1 \mathrm{~kg}$ each) were taken from chopped material to the laboratory and separated into five categories $(<2.0$; " 2.0 to $<4.0$ "; " 4.0 to $<6.0$ "; " 6.0 to $<8.0$ " and $>8.0 \mathrm{~cm}$ ). Each cutting length in the sample was weighed and calculated as a percentage in proportional to the total weight of the sample. Also the average cutting length was calculated at different rotary cutting and forward speed.

Productivity: The theoretical and actual field capacity (fed/h) was calculated at different forward speeds under study. The productivity of the chopping unit (ton/h) under different forward speed were calculated by multiplying the actual field capacity (fed/h) and straw weigh (ton/fed).

Cutting energy requirements: Harvesting energy requirements by combine with $\left(\mathrm{Ew}_{1}\right)$ and without $\left(\mathrm{Ew}_{2}\right)$ chopping unite were estimated from common fuel consumption equations. The difference between $\left(\mathrm{Ew}_{1}\right)$ and $\left(\mathrm{Ew}_{2}\right)$ is the power requirement of chopping unit $\left(\mathrm{Ew}_{3} \mathrm{~kW}\right)$.

$$
\mathrm{Er}=\frac{\mathrm{Ew}_{3}}{\mathrm{Cp}} \mathrm{kW} \cdot \mathrm{h} / \mathrm{ton}
$$

Where:

Er: Energy requirement of shopping unit, $\mathrm{kW} . \mathrm{h} / \mathrm{ton}$

$\mathrm{Cp}$ : chopping productivity, ton/h 


\section{RESULTS AND DISCUSSION}

Many experiments were carried out to select forward speed, rotary cutting speed and overlapping between fixed and rotary knives in order to increase the utilization of combine for chopping rice straw during harvesting operation.

\section{Average cutting length:}

The effects of forward speed on the average cutting length of rice straw are shown in Fig. (3) at different cutting speed. The general trend is that increasing both of forward speed and cutting knives speed decrease the average of cutting length. This my be due to, increase in the amount of stems to be cut by increasing forward speed withal increase cutting knives speed, increase the number of cut per unit time and this lead to decrease the average cutting length and vise-versa. The lowest average of cutting length was obtained at forward speed $0.75 \mathrm{~m} / \mathrm{sec}$ and cutting speed 550 rpm, meanwhile the highest value was obtained at forward speed 0.35 $\mathrm{m} / \mathrm{sec}$ and cutting speed $450 \mathrm{rpm}$. It could be noticed that the chopping system could not be operated at forward speed $0.75 \mathrm{~m} / \mathrm{sec}$ with cutting speed $650 \mathrm{rpm}$ and $1 \mathrm{~m} / \mathrm{sec}$ forward speed with any cutting speed this may be due to when increasing forward speed $(1 \mathrm{~m} / \mathrm{sec})$, the excessive amount of rice straw feeding to rotary cutting drum, this need more power to chop it, therefore the chopper system can't chopped all straws inside chopping unite, finally no oriented average length.

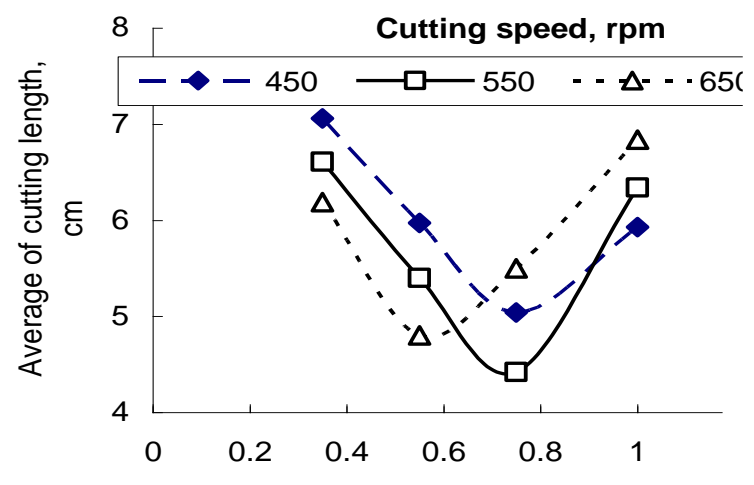

Forward speed, mls

Fig. (3): The average of cutting length via the forward 


\section{Effect of studying factors on cutting length distribution:}

The effect of forward speed, cutting speed and overlapping between fixed and rotary knives on the distribution percentage category of cutting length rice straw are illustrated in Fig. (4). From these data, it could be indicated that the distribution percentage of desirable pieces of chopped straws (from $<2$ to $6 \mathrm{~cm}$ ) was increased and the percentage of undesirable pieces $(>8 \mathrm{~cm})$ was decreased by increasing each of forward speed and cutting speed and vise-versa. The percentage of short pieces $(>6 \mathrm{~cm})$ was increased form 30 to $83 \%$ as increasing forward and cutting speed from $0.35 \mathrm{~m} / \mathrm{s}$ and $450 \mathrm{rpm}$ to $0.75 \mathrm{~m} / \mathrm{s}$ and $550 \mathrm{rpm}$ respectively. For use of composting suitable cut length in average of $1.27-7.62 \mathrm{~cm}$ according to Luis et al. (1993).

The alteration rate in the distribution percentage of short cutting length at any given forward speed was found to be increased with increasing cutting speed and increased slightly as the overlapping between knives increased. The maximum distribution percentage (56\%) of long pieces was obtained at forward and cutting speed $(0.35 \mathrm{~m} / \mathrm{sec}$ and $450 \mathrm{rpm})$ and overlapping, $(6 \mathrm{~cm})$ consequently, the resistance of the stems to bending may becomes less than the resistance to cutting specially rice straw has strong fibers contains silicon can not be cut easily and elongated before cutting, there fore the stem is not cut easily but bends before cutting, this lead to increase cut length. Also, the data revealed that the forward speed of $(0.75 \mathrm{~m} / \mathrm{sec})$ with cutting speed of $650 \mathrm{rpm}$ and forward speed of $(1.0$ $\mathrm{m} / \mathrm{sec}$ ) with any given cutting speed gave non oriented cutting length. Finally the higher percentage $(83 \%)$ of short cutting length was obtained at $(0.75 \mathrm{~m} / \mathrm{sec}, 550 \mathrm{rpm}, 10 \mathrm{~cm})$ forward speed, cutting speed and overlapping respectively.

\section{Productivity:}

The results of field productivity are summarized in Figs. (5 and 6). From these results it could be noticed that the increase in forward speed of the combine translate to increment in chopping productivity. Increasing forward speed from $(0.35-0.75 \mathrm{~m} / \mathrm{sec})$ increasing field capacity from (0.32- $0.68 \mathrm{fed} / \mathrm{h})$ consequently increasing productivity from $(960-2040$ 


\section{F1-Ov1}

Cutter roter revolution, rpm

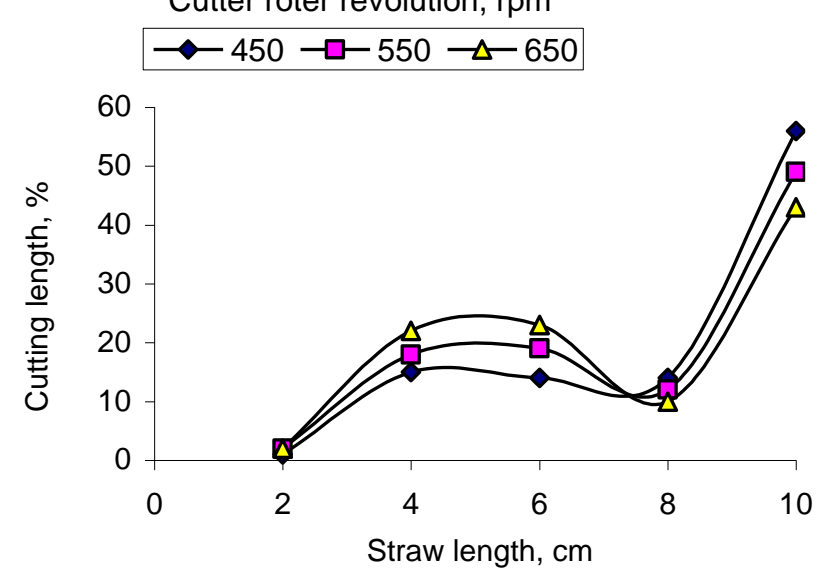

$\mathrm{F} 2-\mathrm{Ov}_{1}$

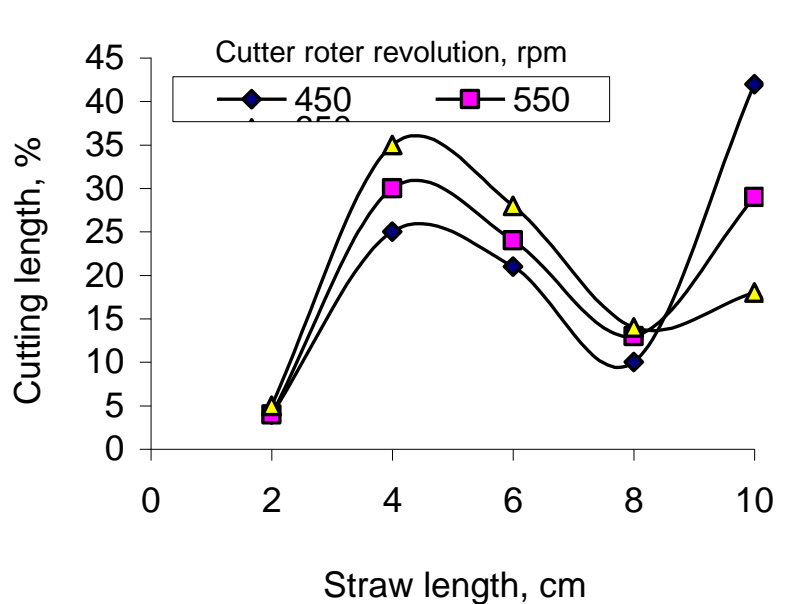

$\mathrm{F} 1-\mathrm{Ov} 2$

Cutter roter revolution, rpm

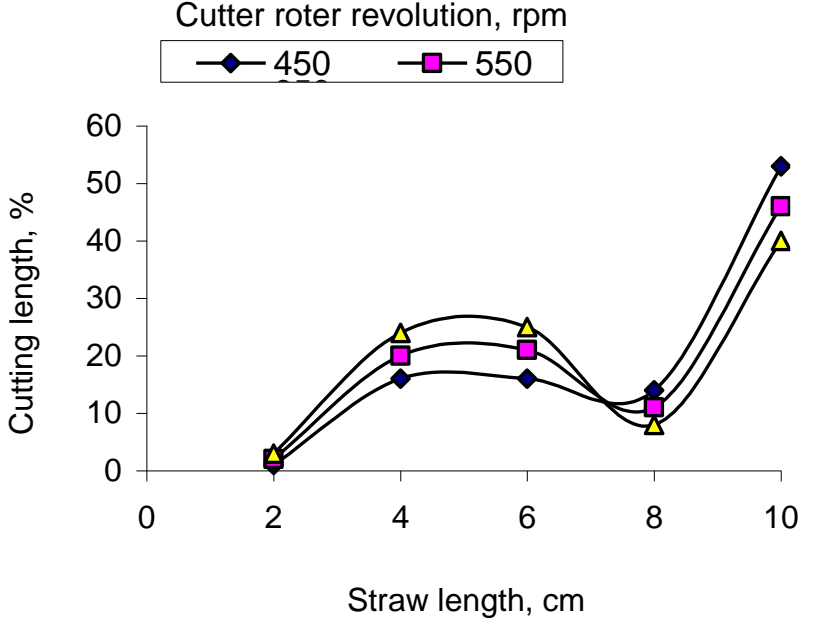

$\mathrm{F} 2-\mathrm{Ov}_{2}$

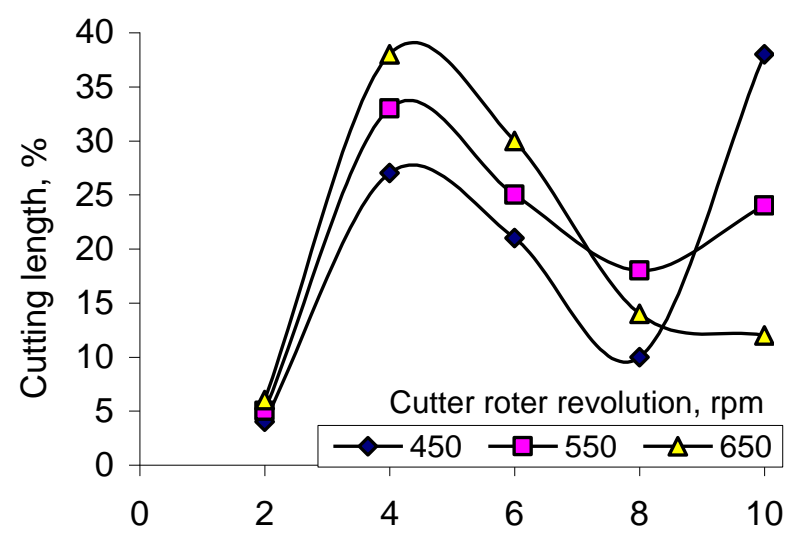

Straw length, $\mathrm{cm}$
F1-Ovy

Cutter roter revolution, rpm $\rightarrow 450 \rightarrow-550 \rightarrow-650$
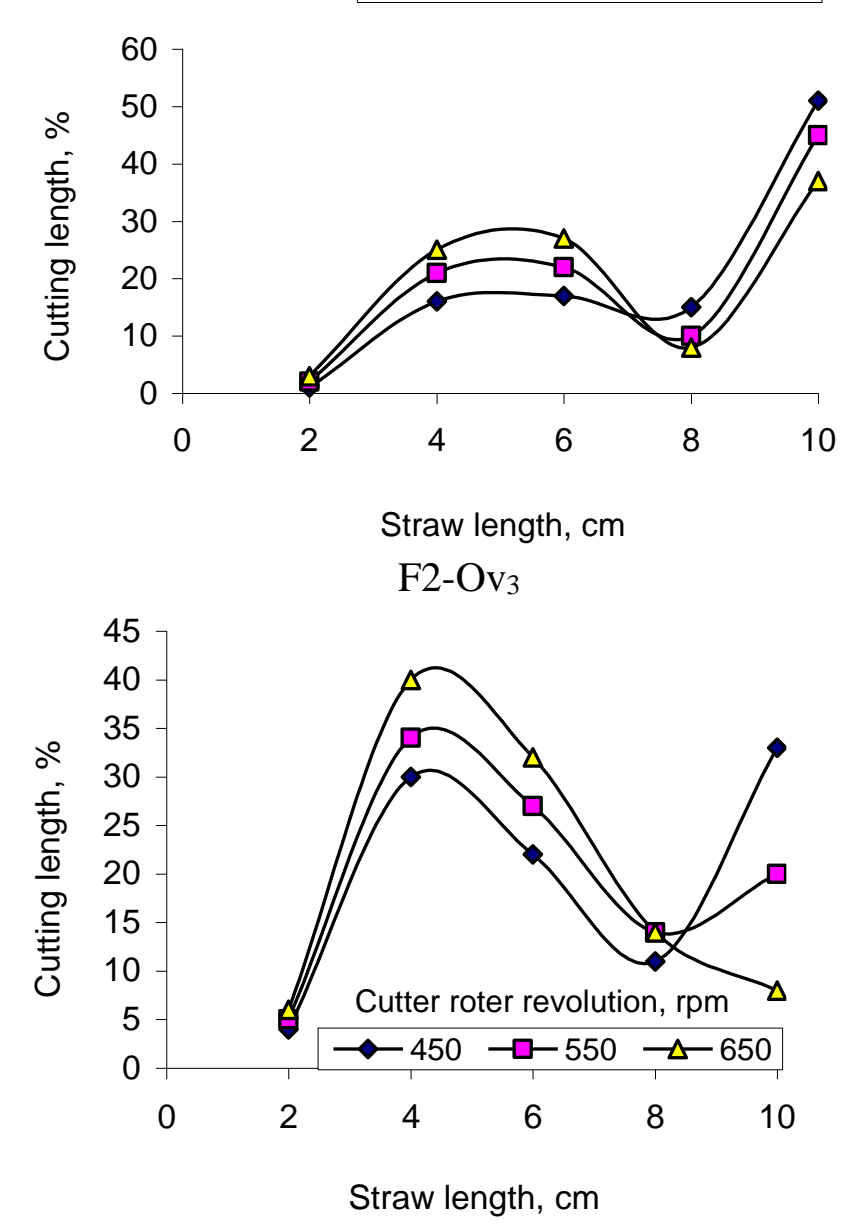

Fig. (4): Effect of studying factors on cutting length distribution 

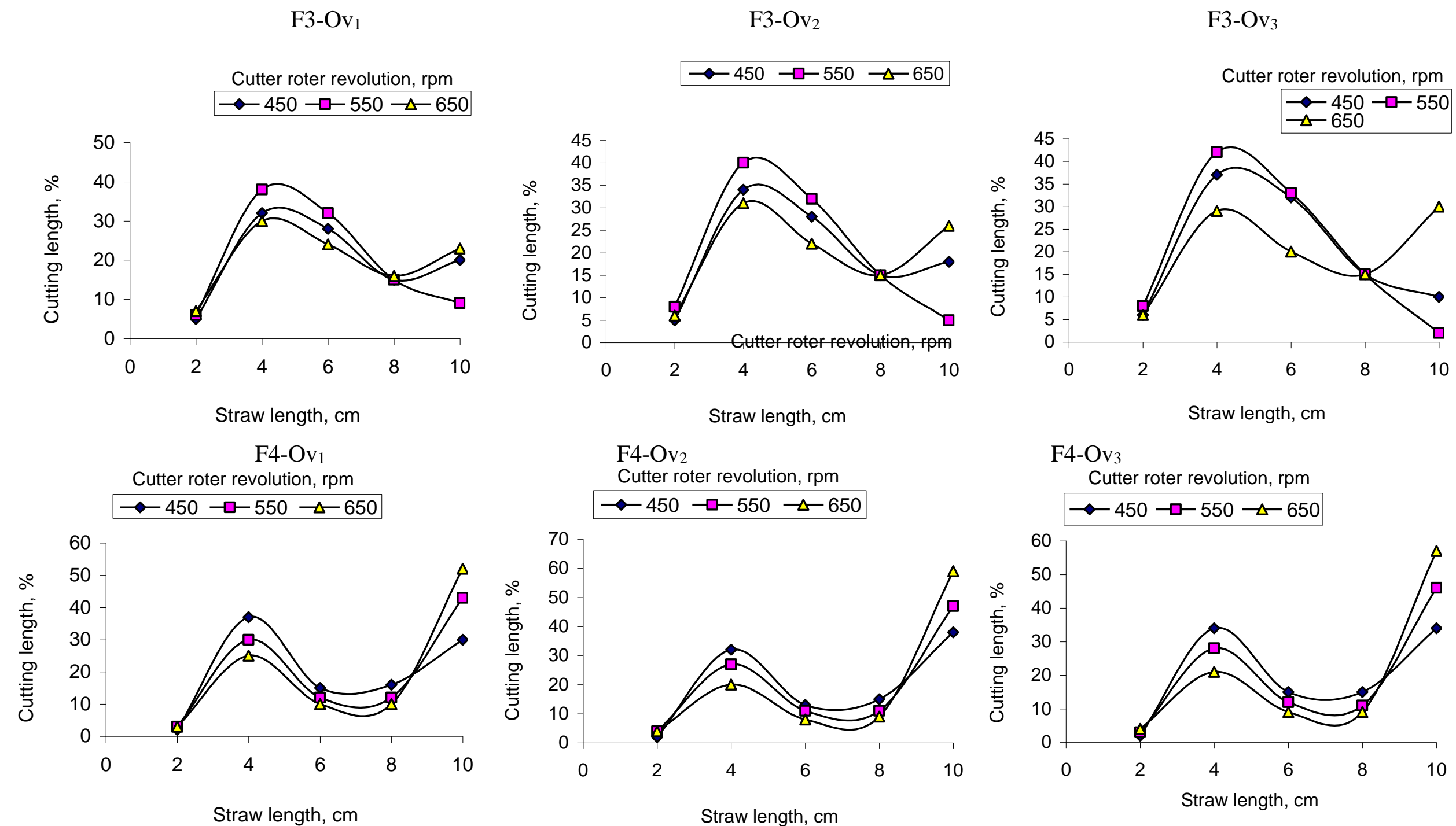

F4-Ov 2

Cutter roter revolution, rpm
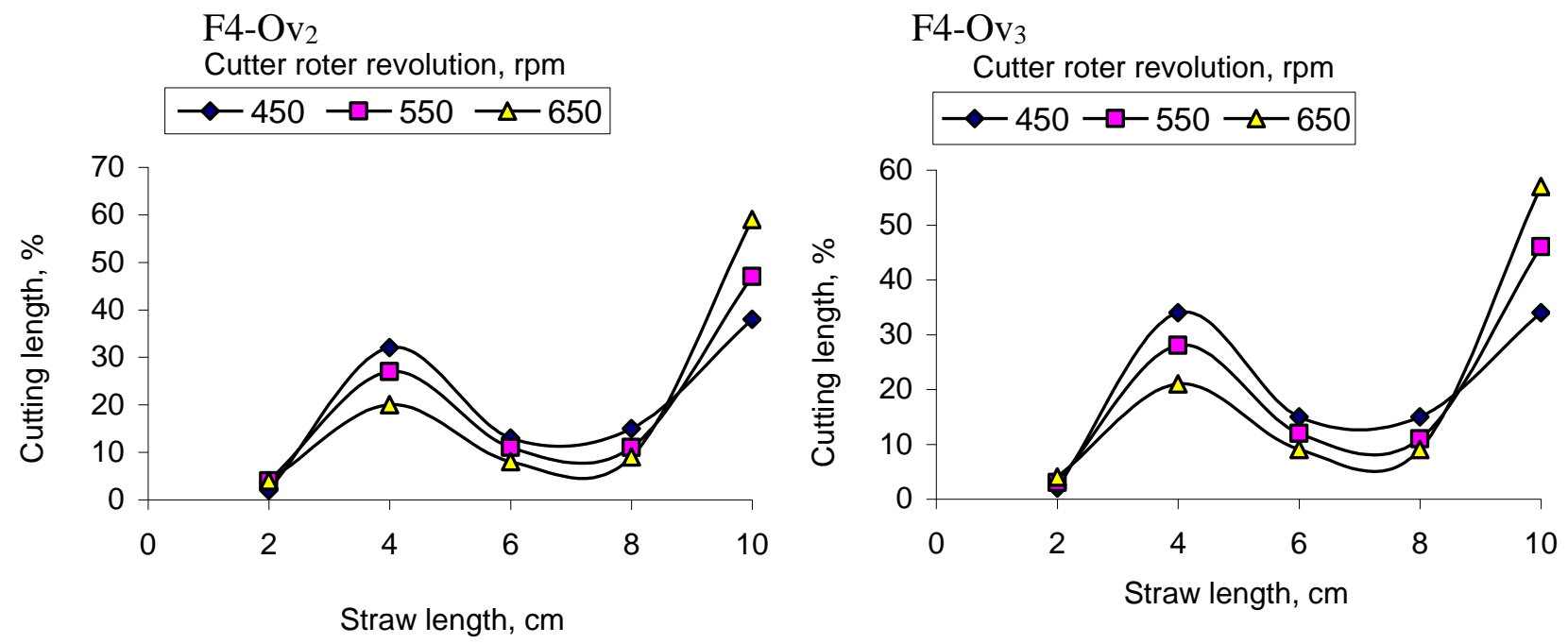

Continues of Fig. (4): Effect of studying factors on cutting length distribution 

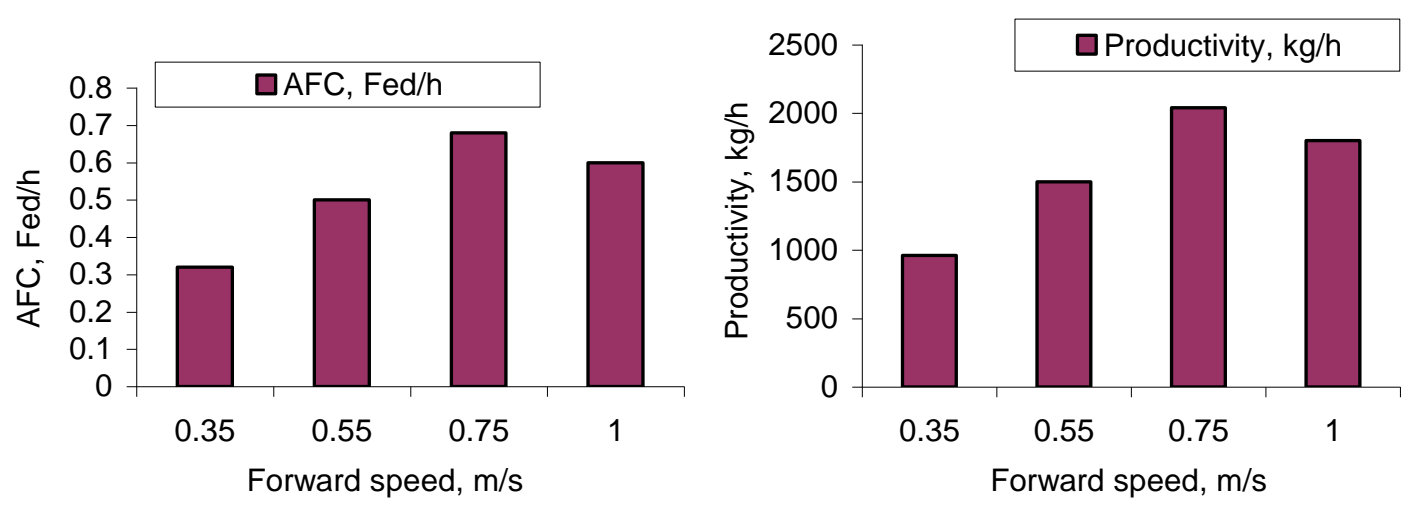

Fig. 5: the field capacity via forward speed Fig. 6: the productivity via forward speed $\mathrm{kg} / \mathrm{h})$. On the other hand, increasing combine forward speed from $(0.75-1.0$ $\mathrm{m} / \mathrm{sec}$ ) at any given cutting speed the filed capacity and productivity decreased. Because of the increasing in forward speed lead to accumulate of rice stems. Consequently, increase of combine trouble and lost time. There fore, it is necessary to adjust forward and cutting speed to obtain the suitable cut length and maximum filed capacity and productivity, this was obtained at forward and cutting speed of $(0.75 \mathrm{~m} / \mathrm{sec})$ and $(550 \mathrm{rpm})$ respectively.

\section{Power consumption and energy required:}

Figs. (7 and 8) show the effect of forward speed on power consumption (kW) and energy requirement $\mathrm{kW} \mathrm{h} / \mathrm{ton}$ at different cutter rotor revolution. The result shows the power consumption for cutting straw rice was increased with increasing forward speed and cutting speed. The minimum value of power consumption was $(15 \mathrm{~kW})$ noticed at $(0.35 \mathrm{~m} / \mathrm{sec}$ and $450 \mathrm{rpm})$ forward and cutting speed respectively. Which, the energy requirement increased with decreasing forward speed and increasing cutting speed. The minimum value of energy requirement was $(25 \mathrm{~kW} \mathrm{h/ton})$ noticed for forward speed $(0.75 \mathrm{~m} / \mathrm{sec})$ and cutting speed (450 rpm)

\section{CONCLUSION}

The modifying chopping system improved combine performance in chopping straw during harvesting process. Experiments indicated that suitable forward and cutting speed and overlapping between fixed and rotary knives are (0.75 $\mathrm{m} / \mathrm{s}, 550 \mathrm{rpm}$ and $10 \mathrm{~cm}$ ) respectively. Also data revealed that, the excessive of forward and cutting speed cause an increase combine trouble.

Misr J. Ag. Eng., April 2009 

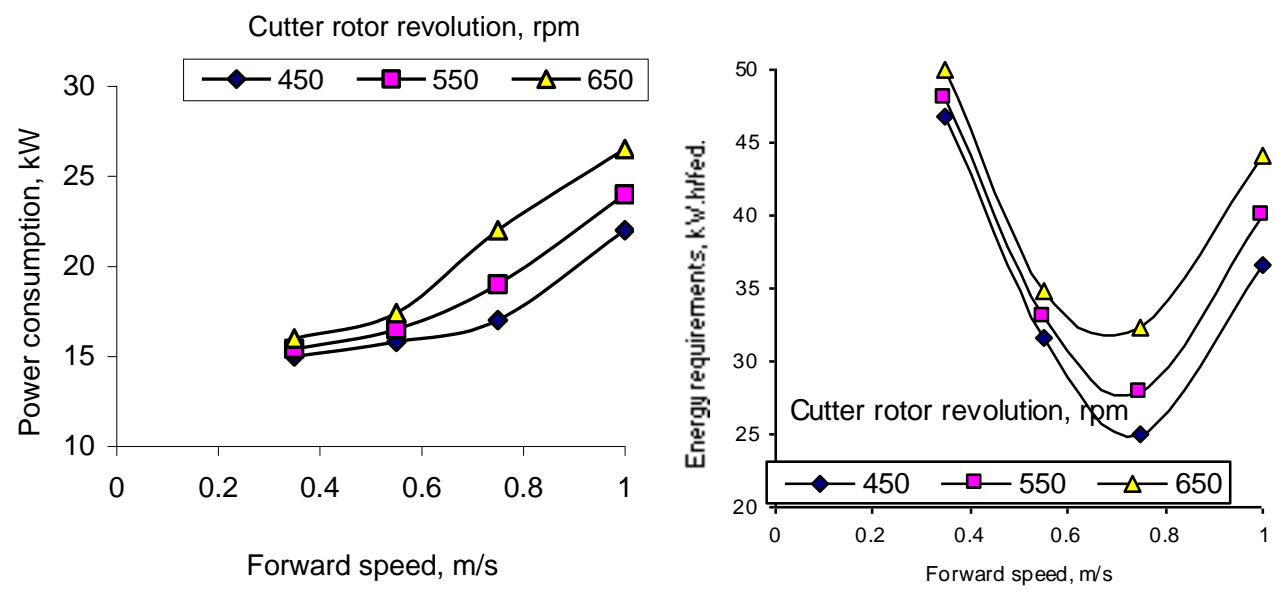

Fig. 7: The power consumption via forward speed Fig. 8: The energy requirement via forward speed

\section{REFRENCES}

Abdel-Maksoud, S.A, A.L.Mousa and A.A.Ibrahim (1988). Energy requirement for locally manufactured combine straw chopper. $1^{\text {st }}$. Conf on Rationalization of energy in agriculture. Agric. Mech. Dept. Fac. of Agri, Mansoura univ: 256-266.

Arif, E.M. (1999). Development and performance of a shredder machine for composting. P.hD. Th. Fac. of Agri. Ain. Shams Univ.

Awady, M.N; Shaaban, 1 Yehia and M.S.Mira (2001). Review on equipment industry for agricultural residues management in egypt. $9^{\text {th }}$ Conf. of Misr Society of Agr. Eng. 9-11 Sep. 2001: 96-108.

EL-Berry, A.M; M.A. Baiomy; H.A. Radwan and E.M. Arif, (2001). Evolution of (Hemtol) machine in rice straw chopping. ${ }^{\text {th }}$-Conf. of Misr Society of Agr. Eng. 9-11Sep. 2001: 65-76.

EL-Eraqi, M. and S.EL. Khawaga (2003). Design and test performance of cutting machine for some crop residues (a). Misr J. Agr. Eng. Jan. 2003: 85-101.

Habib, R.A.; Azzam, B.S.; Nasr, G.M. and Khatab, A.A. (2002). The parameters affecting the cutting process performance of agricultural plants. Misr J. Agr. Eng. 19 (2):361-372.

Imbabi, A, T. Improving a crop residues cutting machine for environment preservation. Misr J. Agr. Eng. July 2003: 783-805. 
Ismail, A.A. (1999). An analysis of combine costs and performance under local conditions. Misr J. Ag. Eng. 16 (4).

Kamel, O.M., M.E. EL-Iraqi, and M.I. Egela. (2003). Maximizing utilization of forage chopper for chapping rice straw residues. Misr. J. Agr. Eng. July 2003: 751-756.

Kanotoski, C.Z. and T. Karwowaki (1976). Agricultural machines theory and construction. Translated by Markiewicz, H. and Bartosezeweski, W.; Warsaw, Poland, Vol. 2. 1976-48-61.

Kepner, R.A; R. Bainer and EL-barger (1993). Principals of farm machinery. AX. Pub. Co. Westport conn-404-468.

Khader, R.A.; R. Bianer and EL-Barger (1993). Principles of farm machinery. Forage chopping and handling. $3^{\text {rd }}$.The AVI Publishing Co. Inch.West-Port, Conn, U.S.A, 368-391.

Luis, F.D.G.M. Savaga; L.L. Eggerth and G.G. Calarence (1993). Composting and recycling municipal salid waste. Lewis. Pub. London.

Nasr, E.M. (2000). Farm waste management and its impact on the environment (Review article). Agr. Eng. Fac. of Agric. Cairo Univ.

Srivastava, A.K.; G.E. Goering and R.P. Rohrbach (1995). Engineering principles of agricultural machines. Hay and forage harvesting. Pamela Dover. Honsen Editor.

Yumnam, J. and S. Protop (1991). Energetic of forage cutting. AMA. Vol. 22. No 1: 59-63.

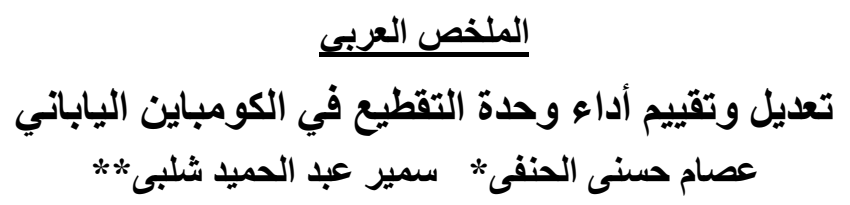

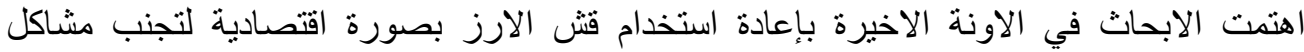

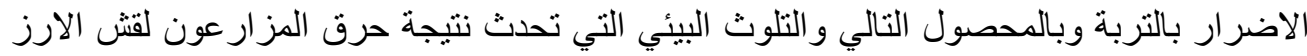

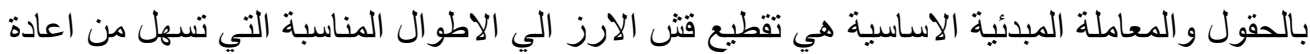

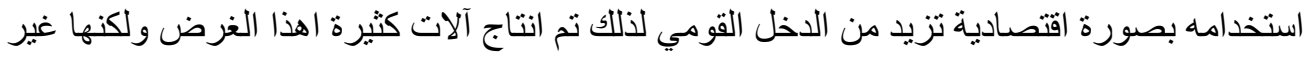
كافية وتزيد من التكاليف علي المزارعين من هنا كان المهم تطوير جهاز التقطيع بالكومباين الياباني

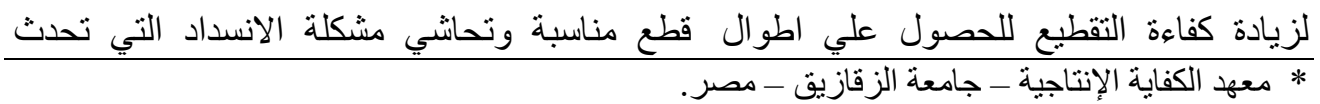
* * معهد بحوث الهندسة الزر اعية ـ الدقى - جيزة - مصر. 
بالكومباين لزيادة الكفاءة الحقلية والإنتاجية وبالتالي معدل الاستفادة من الكومباين تم تطوير جهاز

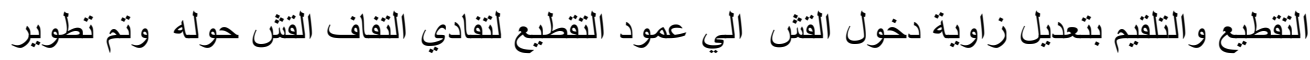

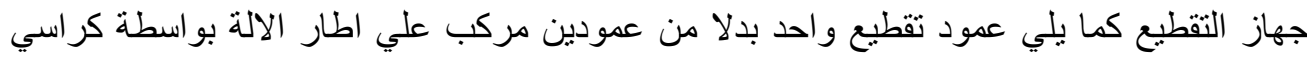

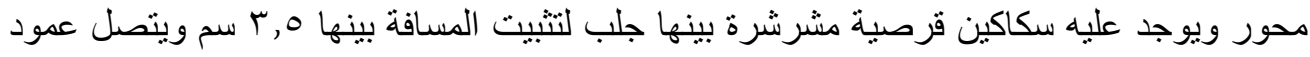

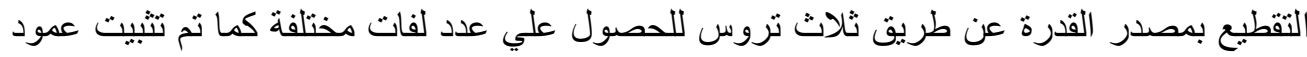

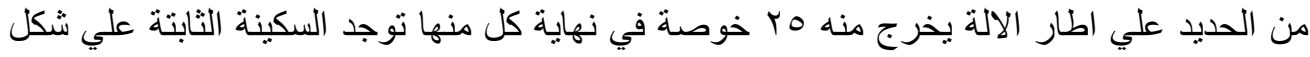

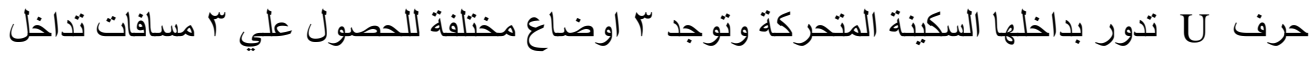

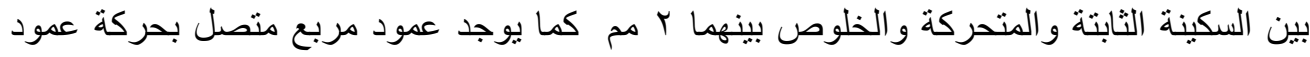

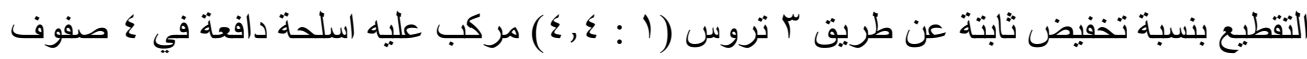

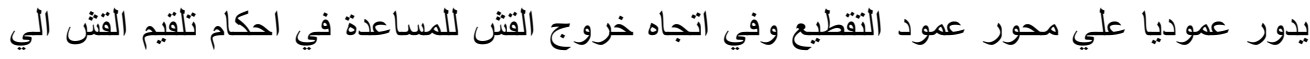

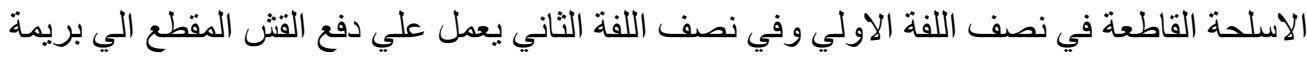
طرد القش وذلك لتلافي تر اكم القش وانسداد غرفة التقطيع وتمت الدراسة تحت تاثير العو امل الاتية :

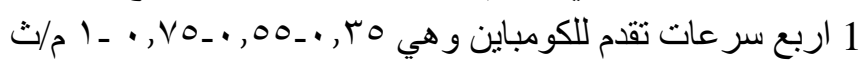

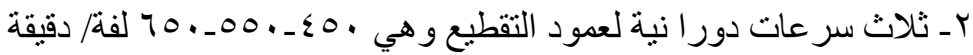

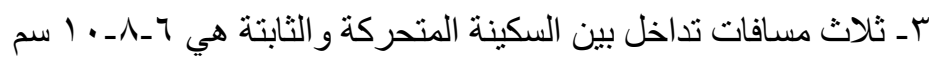

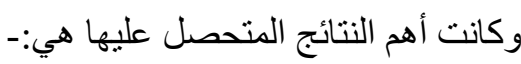

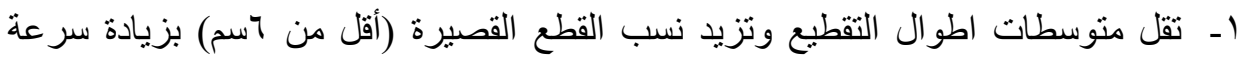

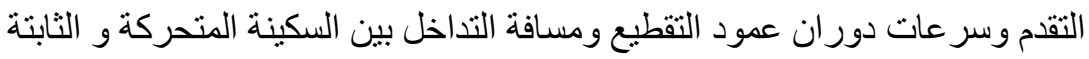

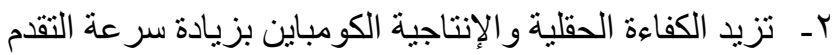

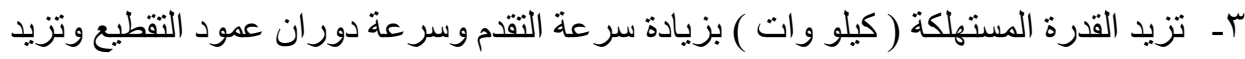

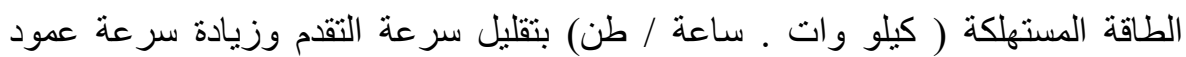

$$
\text { التقطيع. }
$$

ـ- كان اقل متوسط لأطو ال التقطيع و اعلي نسبة للقش القصير (أقل منج سم) عند سر عة تقدم

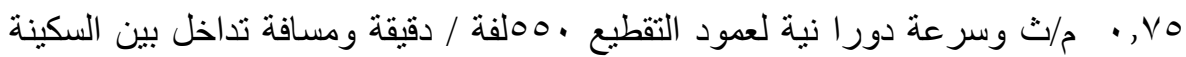

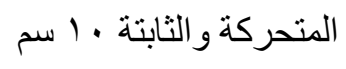

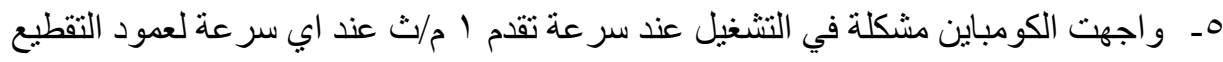

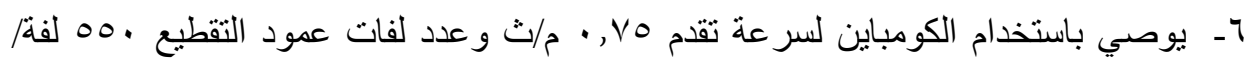

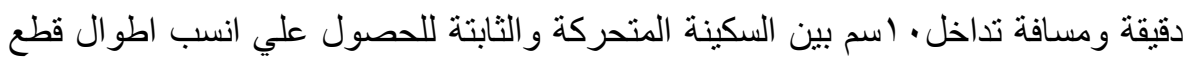
و افضل كفاءة تشغيل للكومباين. 